\title{
Saved from trade: donated and confiscated gibbons in zoos and rescue centres in Indonesia
}

\author{
Vincent Nijman ${ }^{1, *}$, Cho-fui Yang Martinez ${ }^{1}$, Chris R. Shepherd ${ }^{1,2}$ \\ ${ }^{1}$ Oxford Brookes University, School of Social Sciences and Law, Oxford OX3 0BP, UK \\ ${ }^{2}$ TRAFFIC Southeast Asia, Unit 9-3A, 3rd floor, Jalan SS23/11, Taman SEA, Petaling Jaya, Selangor, Malaysia
}

\begin{abstract}
We present data on 600 gibbons in 22 zoos and 9 wildlife rescue centres and reintroduction centres in western Indonesia based on surveys conducted from 2003 to 2008. All gibbon species are protected by Indonesian law and cannot legally be kept as pets. Gibbons rarely breed successfully in Indonesian zoos, and the vast majority of animals present in these collections originate from the illegal wildlife trade, having been donated to the zoos by the public or brought in by Indonesian authorities after being confiscated from dealers or private owners. Gibbons in rescue and rehabilitation centres also derive largely from donations or confiscations. The surveys provide insight into the volume and species composition of gibbons in trade. All 7 species of gibbon that occur naturally in Indonesia were observed, with the highest numbers (130 ind.) being for the siamang Symphalangus syndactylus. About 100 ind. each for Bornean and Sumatran agile gibbons Hylobates albibarbis and $H$. agilis, Javan gibbon $H$. moloch and Müller's gibbon $H$. muelleri were present, but only a handful of white-handed $H$. lar and Kloss' gibbons $H$. klossi. No gibbons that do not occur in Indonesia were recorded. Numbers of the different species in trade appear to be positively related to their numbers in the wild. Trade in Sumatra and Borneo appears to be confined to species naturally occurring there, but all species are traded on Java. About twice as many gibbons were taken in by the respective institutions following confiscations by the Indonesian authorities compared to gibbons received as donations by the public. However, prosecution of offenders is rare, and given the large scale of the gibbon trade, we urge the Indonesian authorities to increase efforts to enforce wildlife protection laws.
\end{abstract}

KEY WORDS: CITES · Conservation · Hylobatidae $\cdot$ Reintroduction $\cdot$ Wildlife trade

\section{INTRODUCTION}

For the successful conservation of primates, and indeed other wildlife, it is essential that the root causes of the threats faced by the different species are properly understood (Broad et al. 2003, Grieser-Johns \& Thomson 2005). The primary extrinsic threats to the majority of primates are unquestionably habitat destruction and hunting, but as remaining populations become increasingly smaller, the effects of secondary threats become more and more important (Cowlishaw \& Dunbar 2000). Trade in primates can have a dramatic effect on the last surviving populations of already rare primates (Kavanagh et al. 1987, Eudey 1999). The trade in live primates is driven by both domestic and international demand from biomedical companies, zoological collections and pet owners. To the naive outsider, it may appear that most of the trade in primates as pets is to meet the international demand, with buyers mostly in developed countries and suppliers mostly operating from developing countries. However, it is becoming increasingly clear that a large proportion of the trade is intended to meet domestic demand in tropical countries (Duarte-Quiroga \& Estrada 2003, Shepherd et al. 2004, Nijman 2006). Furthermore, as there are apparently a large number of affluent buyers in developing countries, there is a market for exotic pets (i.e. those species not indigenous to the country 
itself) within the developing world. With controls being lax in certain countries, this includes species that are legally protected and not allowed in trade. Live primates are traded as pets in many of their countries of origin, but data on such trade are largely lacking.

Here we present data on the trade in primates in western Indonesia. We focus on gibbons, a group of primates that are widely traded as pets, consolidating data from zoos and rescue centres. Indonesia is home to 7 species of gibbon, all of which are listed as Endangered according to IUCN threat criteria, meaning that all species are considered to face a very high risk of extinction in the wild (Andayani et al. 2008, Brockelman \& Geissmann 2008, Geissmann \& Nijman 2008a,b, Nijman \& Geissman 2008, Nijman et al. 2008a,b, Whittaker \& Geissmann 2008). Gibbons are well known to the Indonesian and international public, as are the threats they face. Within Indonesia, they have been legally protected since the first legislation for wildlife protection came into effect in 1925 when the country was still under the Dutch colonial administration. Gibbons are currently protected under the 'Act of the Republic of Indonesia No. 5 of 1990 concerning Conservation of Living Resources and their Ecosystems', widely known as 'Act No. 5'. Act No. 5 makes it illegal to

Catch, injure, care for, transport, and trade in a protected animal in a live condition; Keep, possess, care for, transport, and trade in a protected animal in a dead condition; Transfer a protected animal from one place to another, within or outside Indonesia; Trade, keep or possess skin, bodies, or other parts of a protected animal or the goods made of parts of the animal, or transfer from one place in Indonesia to another, within or outside Indonesia. (p. 12)

Penalties that can be imposed when these laws are broken can total fines of up to IDR 100000000 (USD 9600 at 2009 exchange rates) as well as imprisonment for up to 5 yr.

From its inception in 1975, all species of gibbon have been included in Appendix I of the Convention on International Trade in Endangered Species of Wild Fauna and Flora (CITES), to which Indonesia acceded in 1979, precluding all international trade (Soehartono \& Mardiastuti 2002).

For the present study we tested several specific hypotheses, i.e. (1) zoos want to display not only species native to their own region, whereas rescue centres will focus on threatened species in their region; therefore, we expect differences in species composition between zoos and rescue centres; (2) Indonesian zoos are part of a global community of zoos, with the Indonesian Zoo Association PKBSI, for instance, being a Sustaining Member of the Southeast Asian Zoo Association (SEAZA); we thus expect no differences in species composition between international and Indonesian zoos; (3) there is a positive relationship between the rarity of a species in the wild and total numbers in zoos, in that species with smaller distribution ranges within Indonesia are less commonly found in rescue centres and zoos.

\section{MATERIALS AND METHODS}

The study was part of a wider assessment of trade in Asian apes (Nijman 2005a,b, 2009) It follows a recommendation made by Chen et al. (2004), who surveyed gibbons in 6 zoos in Taiwan, to extend their survey into, among other countries, Indonesia. To put the gibbon trade in Indonesia in an international context, we first present data on the international trade in Indonesian gibbons as reported by Indonesia and importing CITES Parties (data retrieved from www.unep-wcmc. org/citestrade), after which we present data on trade within Indonesia. Data on the extent of occurrence of gibbon species were used as a proxy for population numbers, assuming that species with a greater extent of occurrence would have a larger population size. This was restricted to the range within Indonesia and was estimated from the IUCN Red List database (www.iucnredlist.org).

Data were solicited from 6 wildlife rescue centres (in Indonesian: Pusat Penyelamatan Satwa), i.e. Tegal Alur, Cikanagan, Gadog, Yogyakarta and Petungsewu (Java) and Yayasan Gibbon Indonesia Badung (Bali), and 3 rehabilitation/reintroduction programmes, i.e. Kalaweit Palangkaraya (Borneo), Kalaweit Padang (Sumatra), and the Javan Gibbon Rescue and Rehabilitation Centre (Java). These facilities were visited in the period 2003 to 2008 and where possible, species composition and numbers were updated at the end of 2008 using their online databases. These organisations all work in close collaboration with the regional offices for the conservation of natural resources (Balai Konservasi Sumber Daya Alam, BKSDA), and these offices were frequented to obtain background information on the confiscations.

Indonesian zoo records as well as records from BKSDA show that animals confiscated from trade very frequently end up in zoos. Furthermore, zoos are often willing to accept gibbons that have been kept as pets and are no longer wanted by their owners. Some zoos, certainly in the past but perhaps also in the present, actively acquire wild animals to put on display, including gibbons (e.g. Shepherd \& Magnus 2004). As such, 22 zoological collections in Sumatra, Java, Bali, and Kalimantan were visited: Medan Zoo, Hairos Indah, Murah Indah Varia, Kebun Binatang Siantar, Kasang Kumbang Zoo, Palembang Zoo and Bukittingi Zoo (all Sumatra, and last surveyed in 2008); Pusat Primata Schmutzer, Ragunan, Taman Safari Cisarua, Kebun 
Binatang Bandung, Gembiraloka, Taru Jurug Surakarta, Kebun Binatang Tinjomoyo, Taman Kaloko Widya Mandhala, Kebun Binatang Surabaya and Taman Safari Pasaruan (all Java, and last surveyed in 2004), Bali Zoo Park (Bali, surveyed 2003), Kebun Binatang Pontianak, Taman Ria Wisata Agro, Kebun Binatang Gunung Bayan and Kebun Raya Samarinda (all Kalimantan, last surveyed 2004).

Data on the occurrence of gibbons were first collected by visiting the zoo to check what kind of animals were on display. When keepers were present, they were informally questioned on the total number of gibbons present in their zoo (including those that were not currently on display), their origin and whether breeding attempts had been successful. Only later was a more formal request made to the zoo to obtain data on the origin of their stock.

Data on the species composition of gibbons in international zoos (i.e. zoos outside Indonesia) were retrieved from the International Species Information System (ISIS) website (www.isis.org/CMSHOME/), listing collection information from its 735 institutional members. Gibbons that were listed as hybrids were not included. Since most data collected were not normally distributed, non-parametric tests were used (Siegel \& Castellan 1988). For testing whether the observed frequencies of occurrence were homogeneously distributed over all classes and whether significant differences existed between the different classes, chi-squared tests were used, with Yates' correction for continuity applied where appropriate. Significance was assumed when $\mathrm{p}<0.05$ in a 2-tailed test.

\section{RESULTS}

From 1978 until 2007, at least 69 gibbons (Hylobates agilis, H. lar, H. moloch and Symphalangus syndactylus) were exported from Indonesia (Table 1). Of these, 30 individuals were intended for zoos or for breeding in captivity, 2 for scientific purposes and 8 for commercial trade, with no purpose given for the other transactions. Regarding their origin, it was reported that 17 were born in a captive setting and 9 represented wildcaught individuals. With the exception of the large number exported in 1987 (13 H. moloch and 10 S. syndactylus) numbers in most years were low (Fig. 1).

Within Indonesia, in zoos and rescue centres, we observed a total of 573 gibbons of all species native to Indonesia (Table 2). Within the respective islands, we observed only Sumatran species on Sumatra, only Bornean species on Borneo, and the Javan gibbon was only observed on Java. A wide range of species were observed on Java and Bali (only Javan gibbons are found in the forest of Java, while no gibbons occur naturally in Bali). We recorded no exotic species (that is, any of the 9 species of gibbon that are not found in Indonesia) during our survey.

While more gibbons were observed in the 9 rescue/rehabilitation centres $(\mathrm{n}=335)$ than in the 22 zoos $(\mathrm{n}=238)$, the species composition and relative abundance of the different species was very similar. There was a strong positive correlation between numbers of the different species in zoos and rescue/rehabilitation centres when all data were combined (Pearson's, $\left.N=7, \mathrm{R}^{2}=0.50, \mathrm{p}<0.05\right)$. When exploring the datasets from the 3 islands separately, the similarity between the composition in zoos and rescue/rehabilitation centres becomes even stronger (Sumatra: Pear-

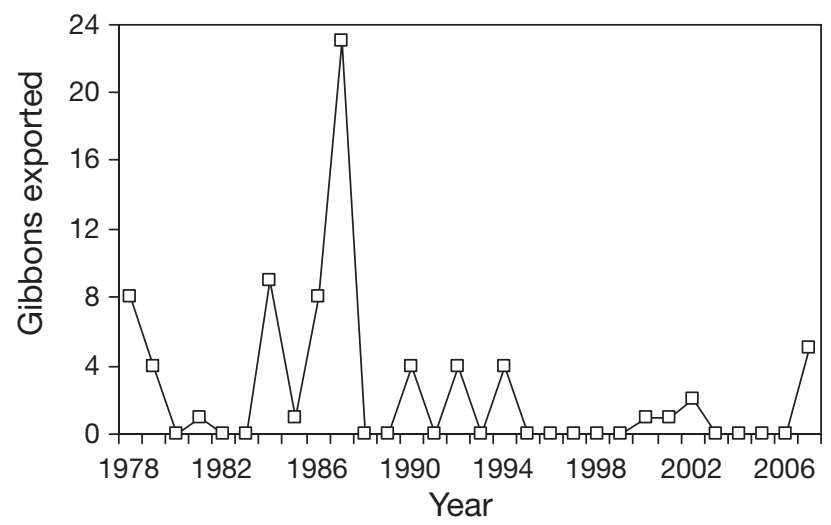

Fig. 1. Number of gibbons (Hylobates spp. and Symphalangus syndactylus) exported from Indonesia as reported in the WCMC CITES Trade Database

Table 1. Purpose of export and source of gibbons (Hylobates spp. and Symphalangus syndactylus) exported from Indonesia in the period 1978 to 2007

\begin{tabular}{|c|c|c|c|c|c|c|c|c|}
\hline \multirow{2}{*}{ Species } & \multirow{2}{*}{ Total } & \multicolumn{4}{|c|}{ - Purpose } & \multicolumn{3}{|c|}{ Source } \\
\hline & & $\begin{array}{l}\text { Breeding } \\
\text { in captivity }\end{array}$ & Scientific & $\begin{array}{l}\text { Commercial } \\
\text { trade }\end{array}$ & Zoos & $\begin{array}{l}\text { Captive } \\
\text { bred }\end{array}$ & $\begin{array}{l}\text { First generation } \\
\text { born in captivity }\end{array}$ & Wild-caught \\
\hline H. agilis & 6 & & & & 2 & 2 & & \\
\hline H. lar & 1 & & & & 1 & 1 & & \\
\hline H. moloch & 27 & 11 & & 4 & 3 & 6 & & 7 \\
\hline S. syndactylus & 35 & 4 & 2 & 4 & 8 & 7 & 1 & 2 \\
\hline
\end{tabular}


Table 2. Number of gibbons (Hylobates spp. and Symphalangus syndactylus) in rescue centres and zoos in western Indonesia, 2004 to 2008. Animals whose natural range includes Sumatra or Borneo are exclusively observed in Sumatra or Borneo, respectively, plus Java (except one species not observed in Java); note that some of the Bornean agile gibbons $H$. albibarbis may be misidentified as Sumatran agile gibbons $H$. agilis. For common names see Table 3

\begin{tabular}{|c|c|c|c|c|c|c|c|c|c|}
\hline \multirow{2}{*}{$\begin{array}{l}\text { Place } \\
\text { observed }\end{array}$} & \multirow[t]{2}{*}{ Range: } & \multicolumn{4}{|c|}{ Sumatra } & \multirow{2}{*}{$\begin{array}{l}\text { Java } \\
\text { H. moloch }\end{array}$} & \multicolumn{2}{|c|}{ Borneo } & \multirow{2}{*}{$\begin{array}{c}\text { Year of } \\
\text { assessmen }\end{array}$} \\
\hline & & S. syndactylus & H. agilis & H. lar & H. klossi & & H. albibarbis & H. muelleri & \\
\hline \multicolumn{10}{|l|}{ Sumatra } \\
\hline Rescue centres & $(\mathrm{n}=1)$ & 74 & 25 & 0 & 1 & 0 & 0 & 0 & 2008 \\
\hline Zoos & $(\mathrm{n}=7)$ & 20 & 10 & 4 & 0 & 0 & 0 & 0 & 2008 \\
\hline \multicolumn{10}{|l|}{ Java (and Bali) } \\
\hline Rescue centres & $(\mathrm{n}=7)$ & 36 & 19 & 0 & 1 & 31 & 11 & 1 & 2004-08 \\
\hline Zoos & $(\mathrm{n}=11)$ & 55 & 36 & 0 & 5 & 55 & 23 & 19 & 2004 \\
\hline \multicolumn{10}{|l|}{ Borneo } \\
\hline Rescue centres & $(\mathrm{n}=1)$ & 0 & 0 & 0 & 0 & 0 & 71 & 65 & 2008 \\
\hline Zoos & $(\mathrm{n}=4)$ & 0 & 0 & 0 & 0 & 0 & 5 & 6 & 2005 \\
\hline Total & & 185 & 90 & 4 & 7 & 86 & 110 & 91 & \\
\hline
\end{tabular}

son's, $N=7, \mathrm{R}^{2}=0.53, \mathrm{p}<0.05$; Java: Pearson's, $\mathrm{N}=7$, $\mathrm{R}^{2}=0.96, \mathrm{p}<0.01$; Borneo: Pearson's, $\mathrm{N}=7, \mathrm{R}^{2}=0.89$, $\mathrm{p}<0.01)$. This correlation is not simply due to gibbons being re-distributed among rescue centres, with Sumatran gibbons sent to Sumatran rescue centres and Bornean gibbons sent to Bornean rescue centres. There is a negative relationship between the extent of occurrence of gibbon species in Indonesia and numbers in Indonesian zoos and rescue centres (Spearman's rho, $\mathrm{N}=7, \mathrm{p}=0.02$ ).

The numbers of the different species of gibbon rescued from the pet trade in Indonesia can be compared to those present in other zoos outside Indonesia (Table 3). For 4 species (Bornean and Sumatran agile gibbons, Javan gibbon and Müller's gibbon), the number in Indonesian zoos and rescue/rehabilitation centres exceeds that in zoos outside Indonesia. Kloss' gibbons are currently only present in Indonesian zoos. On the other hand, some of the more common species in international zoos, such as white-handed gibbons, were rarely encountered in trade in Indonesia. Thus

Table 3. Gibbons (Hylobates spp. and Symphalangus syndactylus) in Indonesian zoos and rescue centres and international zoos (excluding Indonesia and excluding hybrids) showing no correlation between numbers in captivity in Indonesia and elsewhere

\begin{tabular}{|c|c|c|c|}
\hline Species & $\begin{array}{l}\text { Common } \\
\text { name }\end{array}$ & Indonesia & $\begin{array}{c}\text { International } \\
\text { zoos }\end{array}$ \\
\hline S. syndactylus & Siamang & 185 & 302 \\
\hline $\begin{array}{l}\text { H. agilis and } \\
\text { H. albibarbis }\end{array}$ & Agile gibbon & 200 & 42 \\
\hline H. lar & $\begin{array}{l}\text { White-handed } \\
\text { gibbon }\end{array}$ & 4 & 452 \\
\hline H. klossi & Kloss' gibbon & 7 & 0 \\
\hline H. moloch & Javan gibbon & 86 & 50 \\
\hline H. muelleri & Müller's gibbon & 91 & 27 \\
\hline
\end{tabular}

there is a large difference in species composition between Indonesian zoos and rescue/rehabilitation centres, and international zoos $\left(\chi^{2}=613.2\right.$, df $=5$, $p<$ 0.001).

Compared to the number of gibbons donated to zoos and rescue centres by the general public, about twice as many gibbons are reported to have been received as a result of confiscations carried out by BKSDA, police or other government organisations (Table 4). Comparing the ratio of confiscations versus donations between the species, it becomes clear that this differs between species $\left(\chi^{2}=45.1, \mathrm{df}=4, \mathrm{p}<0.01\right.$ : Kloss' gibbon omitted to avoid too many low expected values). This difference is exclusively due to relatively more Javan gibbons being donated compared to all other species combined $\left(\chi^{2}=42.6\right.$, df $\left.=1, p<0.01\right)$, as none of the other comparisons proved to be significantly different.

The majority of these confiscations were carried out in the period of the survey, with few dating back to the late 1990s. While this information is only available for a subset of the total number of gibbons we observed, it is clear that a substantial number of confiscations have been made in recent years.

Table 4. Confiscated versus donated gibbons (Hylobates spp. and Symphalangus syndactylus) as reported by rescue centres and zoos. Note that, for many of the gibbons, the circumstance under which the animal was received is unknown

\begin{tabular}{|lcc|}
\hline Species & Confiscated & Donated \\
\hline S. syndactylus & 45 & 15 \\
H. agilis & 27 & 9 \\
H. klossi & 2 & 0 \\
H. moloch & 10 & 32 \\
H. albibarbis & 34 & 7 \\
H. muelleri & 6 & 0 \\
\hline
\end{tabular}




\section{DISCUSSION}

This study is one of few to specifically address trade in a primate group in a range country. For Mexico, Cuaron (2005) and Duarte-Quiroga \& Estrada (2003) focussed on aspects of the primate trade by quantifying the number of donated and confiscated animals that arrived in a zoo, and by assessing welfare aspects of primates being kept as pets in the country's capital, respectively. Most of the gibbons we observed in our study originated from the illegal domestic pet trade; thus, our data present a picture of the species composition and magnitude of the gibbon trade in Indonesia.

In comparison to the legal international trade in Indonesian gibbons, the domestic trade in Indonesia is large. The similarity in species composition and relative abundance of gibbons in rescue centres and zoos within Java, Sumatra and Borneo, and the large differences, especially between Sumatra and Borneo, suggest that the gibbons in these facilities derive from a similar pool. Many of the zoos admitted that they do not breed gibbons (lack of proper facilities in the majority of the zoos and solitary housing of gibbons makes breeding highly unlikely). Indeed, the majority of gibbons in zoos are animals confiscated by the authorities or unwanted pet gibbons received directly from the public. Therefore, we feel that our study presents a fair representation of the numbers and relative abundance of the different species of gibbon in trade in western Indonesia. While trade has been identified as a modest threat to gibbons in Indonesia (Supriatna et al. 2001, Campbell et al. 2008) this is one of the first attempts to quantify the levels of trade that the different species are subjected to (but see Malone et al. 2002 , 2004). While accurate data are not available, all of the evidence suggests that for each individual gibbon in trade, an unknown number of others have died (Nijman 2005a). Most gibbons in trade have been taken from the wild when they were young, and often not yet weaned, suggesting that at least the mother was killed in order to obtain the young. This is furthermore reflected in the skewed age distribution in zoos and rescue centres, with an over-representation of young individuals (Chen et al. 2004, Nijman 2009). Exacerbated by the illegality of the trade, conditions on markets and during transport to and between markets are far from optimal (V. Nijman \& C. R. Shepherd pers. obs.) and this likely will lead to increased levels of mortality. On the whole, it is safe to assume that a significant number of gibbons have been lost from the wild population in addition to those observed in zoos and rescue centres.

We found a significant positive relationship between a species' extent of occurrence and numbers observed in zoos and rescue centres. If a species' extent of occur- rence is indeed indicative of its population size, as we believe it is, then it appears that species with larger population sizes, and probably a greater availability, are more prevalent in trade. An earlier study found no relationship between a gibbon species' rarity (either in the wild or in trade) and the retail price in animal markets on Java (Nijman 2005a). Combined, these data may suggest limited preference for particular species, with numbers in trade reflecting availability.

It is clear that both Sumatra and Borneo are source regions for the gibbon trade, with a large number of individuals being kept as pets on the islands (Malone et al. 2002, 2004, Nijman 2005b, 2009). There appears to be little exchange of pet gibbons between the 2 islands. Java, the economic and commercial centre of Indonesia, is one of the regions to which gibbons are transported. While we have the impression that a large number of the gibbons in trade are used to supply domestic demand, it is uncontested that a certain proportion is (illegally) exported. Note that the large discrepancy between the relatively small number of gibbons exported from Indonesia after it acceded to CITES (in 1979) and the large number of species occurring in Indonesia in international zoos may, besides successful breeding, indicate illegal trade, poor reporting, or pre-CITES exports. Apart from the lar gibbon, all species occurring in Indonesia are either endemic to the country (Hylobates moloch, H. klossi, H. albibarbis) or occur in Indonesia and Malaysia (Symphalangus syndactylus, $H$. agilis) or Indonesia, Malaysia and Brunei (H. muelleri). Reported exports from Malaysia (7 S. syndactylus and $1 H$. agilis) and Brunei $(2 H$. muelleri) are low, however, and do not resolve this discrepancy.

With almost 350 gibbons in rescue and rehabilitation centres and a large proportion of the $\sim 250$ gibbons in zoos deriving from trade, it is clear that Indonesia must take urgent action to prevent wild populations of gibbons from further decline. With respect to orang-utans Pongo pygmaeus and $P$. abelii in rescue and rehabilitation centres, the CITES/GRASP Orang-utan Technical Mission to Indonesia (Virtue \& Sellars 2006) noted:

Whatever form the trade takes and whatever motivates it, the overwhelming evidence of the scale and seriousness of the problem is the number of orang-utans in 'rescue' and 'rehabilitation' centres. In Kalimantan alone, this is approaching 1000 animals. It is hard to think of another CITES Appendix-I species, in any other country, where individuals are so regularly being confiscated or taken into the care. Indeed, it is hard to view this figure as anything other than an indictment against the law enforcement efforts of the relevant agencies in Indonesia. (p. 11)

While numbers are not as high for any of the species of gibbon, like the orang-utans, all species are considered globally threatened, and are listed in CITES Appendix I. Leighton \& Whitten (1984) argued that one 
of the greatest accomplishment of rehabilitation centres could be their effect on lowering levels of illegal trade. As the rate of confiscations increased, trade is believed to have declined (Leighton \& Whitten 1984). However, it appears that the number of 'rescued' gibbons in rescue and rehabilitation centres, and indeed in zoos, is limited by the number of gibbons that these centres can take in, as opposed to the number of gibbons ready to be confiscated (each time a new facility opens, there is a spike in the number of animals that are taken $\mathrm{in}_{\text {i }}$ this quickly levels off as the facilities reach their carrying capacity: Nijman 2009, V. Nijman unpubl. data).

Zoos can play an important role in the conservation of threatened gibbons (Chen et al. 2004, Nijman 2006). Many of the zoos included in our survey are either institutional members of SEAZA or sustaining members of SEAZA through the Indonesian Zoological Parks' Association. While conservation-orientated ex situ breeding programmes and reintroduction programmes are part of SEAZA's agenda (Wong 2007), it is unlikely that any of the gibbons we encountered in the zoos will be released into the wild (see Cheyne et al. 2008, Cheyne in press, this Theme Section for proper reintroduction guidelines in an Indonesian context and Bennett 1992 for a case study with Müller's gibbons). In view of the fact that many of the gibbons in the rescue/rehabilitation centres will not be returned to the wild (due to behavioural/medical problems with the animals themselves, lack of suitable habitat, and financial and other constraints), these animals may provide an important source for ex situ conservation programmes.

While a large number of the gibbons we encountered were the result of confiscations by the authorities, especially in the case of Javan gibbons and siamangs, many gibbons were received as donations. Donations include the hand-over of gibbons to rescue centres after the authorities detected the gibbons in illegal possession (Nijman 2005a). In the current political context in Indonesia and in terms of law enforcement, the difference between donations and confiscations appears to be largely semantic, as in reality very few people are prosecuted (and even fewer are convicted) for illegal possession of, or trade in, protected wildlife (Nijman 2005a,b).

While we do not wish to downplay the importance of increased habitat protection and more effective conservation area management, we conclude that trade in gibbons in Indonesia is significant, affecting their status, and that this is partially due to a lax interpretation of wildlife protection laws. A thorough review of the effectiveness of the legal and jurisdictional system is timely, and a strength and weakness analysis needs to be performed. The law-enforcement hierarchy needs to be targeted to persuade officials to convict traders, owners and others, and attention needs to be given to providing incentives for law enforcers to carry out their duties with greater efficiency. It is the responsibility of the national offices up to the ministerial level to direct their subordinates to enforce wildlife protection laws as intended. The current laissez-faire attitude, where trade in wildlife is not considered a problem, not even by the authorities that should uphold the wildlife protection laws, should not be tolerated.

Acknowledgements. We thank the Primate Society of Great Britain for organising the 'Measuring and mitigating trade in primates' conference in London. Most of the surveys were carried out as part of a collaborative initiative between TRAFFIC Southeast Asia and the Biodiversity Conservation Office of the Directorate General of Forest Protection and Nature Conservation. A large number of people helped us collect data over the last $6 \mathrm{yr}$; a full list is presented in the 3 TRAFFIC reports authored by V.N. Here we thank the staff and management of all zoos and rescue and rehabilitation centres for their help and support, acknowledging that we could not have completed the studies without them. C.Y.M. was funded by an Undergraduate Research Scholarship from the Centre for Excellence in Teaching and Learning, Oxford, and the TRAFFIC surveys were made possible through grants from WWF-Germany, WWF-Netherlands and WWF-UK. The contents of this publication do not necessarily reflect the views or policies of the funding agencies, and the funders had no role in the study design, data collection and analysis, decision to publish, or preparation of the manuscript. We thank 4 reviewers for helpful suggestions.

\section{LITERATURE CITED}

Andayani N, Brockelman W, Geissmann T, Nijman V, Supriatna J (2008) Hylobates moloch. In: 2008 IUCN Red List of Threatened Species. Available at www.iucnredlist.org (accessed on 22 January 2009)

Bennett J (1992) A glut of gibbons in Sarawak - is rehabilitation the answer? Oryx 26:157-164

Broad S, Mulliken T, Roe D (2003) The nature and extent of legal and illegal trade in wildlife. In: Oldfield S (ed) The trade in wildlife. Regulation for conservation. Flora and Fauna International, Resource Africa and TRAFFIC International, London, p 3-22

Brockelman W, Geissmann T (2008) Hylobates lar. In: 2008 IUCN Red List of Threatened Species. Available at www.iucnredlist.org (accessed on 22 January 2009)

Campbell C, Andayani N, Cheyne S, Pamungkas J and others (2008) Indonesian gibbon conservation and management workshop. Final report. IUCN/SSC Conservation Breeding Specialist Group, Apple Valley, MN

Chen HC, Geissmann T, Chen PC (2004) A survey of the taxonomic status of captive gibbons in Taiwan. Raffles Bull Zool 52:265-269

Cheyne SM (2009) Challenges and opportunities of primate rehabilitation - gibbons as a case study. Endang Species Res 9:159-165

Cheyne SM, Chivers DJ, Sugardjito J (2008) Biology and behaviour of reintroduced gibbons. Biodivers Conserv 17:1741-1751

Cowlishaw G, Dunbar RIM (2000) Primate conservation biology. University of Chicago Press, London 
Cuaron AD (2005) Further role of zoos in conservation: monitoring wildlife use and the dilemma of receiving donated and confiscated animals. Zoo Biol 24:115-124

Duarte-Quiroga A, Estrada A (2003) Primates as pets in Mexico City: an assessment of the species involved, source of origin, and general aspects of treatment. Am J Primatol 61:53-60

Eudey AA (1999) Asian primate conservation - my perspective. In: Dolhinow P, Fuentes A (eds) The nonhuman primates. Mayfield, Mountain View, CA, p 151-158

Geissmann T, Nijman V (2008a) Hylobates agilis. In: 2008 IUCN Red List of Threatened Species. Available at www.iucnredlist.org (accessed on 22 January 2009)

Geissmann T, Nijman V (2008b) Hylobates muelleri. In: 2008 IUCN Red List of Threatened Species. Available at www.iucnredlist.org (accessed on 22 January 2009)

Grieser-Johns A, Thomson J (2005) Going, going, gone: the illegal trade in wildlife in East and Southeast Asia. World Bank, Washington, DC

Kavanagh M, Eudey AA, Mack D (1987) The effect of live trapping and trade on primate populations. In: Marsh CW, Mittermeier RA (eds) Primate conservation in the tropical rain forests. Alan Liss, New York, p 147-177

Leighton DR, Whitten AJ (1984) Management of free-ranging gibbons. In: Preuschoft H, Chivers DJ, Brockelman WY, Creel N (eds) The lesser apes: evolutionary and behavioural biology. Edinburgh University Press, Edinburgh, p 32-43

Malone NM, Purnama AR, Wedana M, Fuentes A (2002) Assessment of the sale of primates at Indonesian bird markets. Asian Primates 8:7-11

Malone NM, Fuentes A, Purnama AR, Adi Putra IMW (2004) Displaced hylobatids: biological, cultural, and economic aspects of the primate trade in Java and Bali, Indonesia. Trop Biodivers 40:41-49

Nijman V (2005a) In full swing. An assessment of trade in orang-utans and gibbons on Java and Bali, Indonesia. TRAFFIC Southeast Asia, Petaling Jaya

Nijman V (2005b) Hanging in the balance. An assessment of trade in orang-utans and gibbons on Kalimantan, Indonesia. TRAFFIC Southeast Asia, Petaling Jaya

Editorial responsibility: Serge Wich,

Des Moines, Iowa, USA
Nijman V (2006) In-situ and ex-situ status of the Javan gibbon and the role of zoos in conservation of the species. Contrib Zool 75:161-168

Nijman V (2009) An assessment of trade in orang-utans and gibbons on Sumatra, Indonesia. TRAFFIC Southeast Asia, Petaling Jaya

Nijman V, Geissman T (2008) Symphalangus syndactylus. In: 2008 IUCN Red List of Threatened Species. Available at www.iucnredlist.org (accessed on 22 January 2009)

Nijman V, Ng J, Shepherd CR (2008a) Trade in Borneo's orang-utans and gibbons. In: Persoon GA, Osseweijer M (eds) Reflections on the heart of Borneo. Tropenbos Ser 24. Tropenbos Foundation, Wageningen, p 121-128

Nijman V, Richardson M, Geissmann T (2008b) Hylobates albibarbis. In: 2008 IUCN Red List of Threatened Species. Available at www.iucnredlist.org (accessed on 22 January 2009)

Shepherd CR, Magnus N (2004) Nowhere to hide: the trade in Sumatran tiger. TRAFFIC Southeast Asia, Petaling Jaya

Shepherd CR, Sukumaran J, Wich SA (2004) Open season: an analysis of the pet trade in Medan, Sumatra 1997-2001. TRAFFIC Southeast Asia, Petaling Java

Siegel S, Castellan NJ (1988) Nonparametric statistics for the behavioral sciences. McGraw-Hill Book Company, New York

Soehartono T, Mardiastuti A (2002) CITES implementation in Indonesia. Nagao Natural Environment Foundation, Jakarta

Supriatna J, Manansang J, Tumbelaka L, Andayani N and others (2001) Conservation assessment and management plan to the primates of Indonesia: final report. Conservation Breeding Specialist Group (SSC/IUCN), Apple Valley, MN

Virtue M, Sellar JM (2006) CITES/GRASP Orang-utan technical mission Indonesia. CITES and GRASP, Gland

Whittaker D, Geissmann T (2008) Hylobates klossii. In: 2008 IUCN Red List of Threatened Species. Available at www.iucnredlist.org (accessed on 22 January 2009)

Wong TS (ed) (2007) SEAZA future 2015. South East Asian Zoo Association, Bogor

Submitted: February 16, 2009; Accepted: June 23, 2009

Proofs received from author(s): October 7, 2009 